DOI 10. 18307/2018. 0218

(C) 2018 by Journal of Lake Sciences

\title{
太湖流域平原水网区浅层地下水动态特征及影响因素”
}

\author{
徐 羽 $^{1}$, 许有鹏 ${ }^{1 * *}$, 吴 雷 $^{1}$, 王 强 ${ }^{1}$, 高 斌 ${ }^{1}$, 周 毅 ${ }^{2}$ \\ (1: 南京大学地理与海洋科学学院, 南京 210023) \\ (2: 江苏省水文水资源勘测局, 南京 210029)
}

\begin{abstract}
摘 要: 鉴于浅层地下水在维持区域生态功能方面的重要作用,基于 2005- 2015 年太湖平原水网地区苏州市的 14 个浅 层地下水监测井水位及 $2005-2014$ 年降水、河道水位和蒸发等日尺度数据, 开展浅层地下水埋深动态特征及影响因素研 究. 结果显示: 苏州市浅层地下水总体呈由北往南、自西向东的流场方向, 主要受地形因素的影响; 年际及丰水期埋深有 所减小, 枯水期反之, 各区域变化过程不一致; 枯水期浅层地下水动态特征受不同量级降水总量和次数的显著影响,且与 地表水过程关系密切, 汗期反之. 此外均受到引排水和下垫面变化等因素的影响; 浅层地下水埋深对降水具有滞后性, 多 滞后 1 2 d; 通过对地形地貌条件、土地利用类型、河湖密度以及浅层地下水埋深状况等因素的综合分析, 浅层地下水动 态特征可表达为耕地区、水网密布区、高度城镇化区及低山林区 4 种特征类型.
\end{abstract}

关键词: 浅层地下水;时空动态; 影响因素;滞时;分区;平原水网区;太湖流域

\section{Characteristics of shallow groundwater and its influences in plain river network region of Taihu Basin}

\author{
XU Yu ${ }^{1}$, XU Youpeng ${ }^{1 * *}$, WU Lei ${ }^{1}$, WANG Qiang ${ }^{1}$, GAO Bin ${ }^{1} \&$ ZHOU Yi ${ }^{2}$ \\ (1: School of Geographic and Oceanographic Sciences, Nanjing University, Nanjing 210023, P.R.China) \\ (2: Jiangsu Province Hydrology and Water Resources Investigation Bureau, Nanjing 210029, P.R.China)
}

\begin{abstract}
In view of the important role in the maintenance of regional ecologic function, the spatio-temporal characteristics of shallow groundwater burial depth (SGBD) and its influential factors were studied based on the daily SGBD data (from 2005 to 2015 ) and regional precipitation, water level and evaporation data (from 2005 to 2014) in Taihu Basin. The results indicated that: The shallow groundwater in Suzhou showed a flow direction from north to south, and from west to east, which is mainly affected by regional topographic conditions. The regional SGBD showed a slightly reduction in annual and flood season scale, while increase in non-flood seasons. The change processes varied among regions. The variation of SGBD is significantly related to the amount and frequency of different precipitation ranks in non-flood seasons, and affected by surface water. Moreover, the diversion and drainage, and underlying surface change were also the influential variables. While these features were opposite in flood seasons. The variation of SGBD often lags 1 to 2 days to precipitation. The characterization of shallow groundwater could be divided to four types, such as the agricultural, watery, urbanized and low mountainous regions, through the overlay of the influential variables, such as geomorphologic conditions, land use types, densities of rivers and lakes, and shallow groundwater burial depth.
\end{abstract}

Keywords: Shallow groundwater; spatial and temporal variation; influential variables; lag time; regional division; plain river network region; Taihu Basin

流域下游平原地区浅层地下水因紧临地表, 与地表水和大气水之间的交换更加频繁, 易受到地理条件、 气候及人类活动的影响, 并存在反馈作用, 对区域生态环境及水资源供给安全等方面均具有重要作用,是水

* 国家重点基础研究发展计划项目 (2016YFC0401502)、国家自然科学基金项目 $(41771032,41371046)$ 和江苏省水利 科技重点基金项目 (2015003) 联合资助. 2016-12-13 收稿;2017-04-15 收修改稿. 徐羽(1989 ), 男,博士研究 生; E-mail: xuyu906@163.com.

** 通信作者; E-mail: xuyp305@163.com. 
文过程变化的重要环节,也是地理和水文学界研究的热点问题之一.

当前, 国外对浅层地下水的研究较多,主要利用水文实验、数理统计及模型模拟等手段,探讨气候变化、 农业生产及城镇化等诸多因素对浅层地下水动态及属性特征的影响 ${ }^{[1-5]}$. 如, Sanderson 和 Cooper 定量揭示 了 San Luis 山谷蒸发对浅层地下水动态过程的影响 ${ }^{[1]}$; Cai 和 Ofterdingter 发现北爱尔兰地区浅层地下水对 降水的响应时间多在 1 2 h 左右 ${ }^{[2]}$; Barron 等发现澳大利亚西部的 Southern 河流域城镇化导致径流系数由 0.01 显著增加为 0.40 , 下渗量由 $8.08 \mathrm{GL}$ 下降到 $4.21 \sim 6.01 \mathrm{GL}$, 浅层地下水补给量下降 ${ }^{[3]}$. 国内在浅层地下 水研究方面尚处于起步阶段, 研究主要集中在中国北方地区. 研究发现, 我国北方浅层地下水动态受到降水 特征、农业灌溉、地表水补给及气候变化等多个驱动因素的综合影响, 总体表现为埋深不断加大的趋势, 并 表现出时空差异 ${ }^{[6-8]}$; 王仕琴等依据区域特征, 将华北平原浅层地下水划分为 6 大类型 ${ }^{[9]}$; 此外, 南部湿润区 浅层地下水变化过程主要受气候条件的影响, 对人类活动的响应相对微弱 ${ }^{[10-11]}$.

长三角太湖流域降水丰富, 是中国最为典型的平原水网区之一; 同时, 经济社会高度发达, 城镇化导致 不透面积大幅增加, 人类活动对水循环过程影响十分强烈. 开展变化环境下平原水网区浅层地下水探究, 将 为城镇化下区域三水转换规律和产汇流机制分析提供重要支持. 因此, 以太湖平原水网区的苏州市为典型 区, 着重探讨高度城镇化下近 $10 \mathrm{a}$ 浅层地下水动态特征, 揭示其与降水、地表水、蒸发等因素间的关联程度; 并根据主要影响因素, 采用空间叠加分析方法, 对区域浅层地下水变化特征分区进行探讨, 以期更加深刻地 认识自然系统的工作机理,为水资源科学评价、合理开发与保护提供新视角.

\section{1 研究区概况、数据情况与研究方法}

\section{1 研究区概况}

苏州市位于苏南地区,为典型的平原水网区. 本文研究区 (图 1) 为苏州市 (不含太湖部分), 面积约 6665 $\mathrm{km}^{2}$. 苏州市地势低缓, 自北向南、自西向东略有倾斜. 属亚热带季风气候, 四季分明. 近年来, 经济社会快速 发展, 下垫面变化显著. 近 $30 \mathrm{a}$ 苏州城镇建设用地面积增长率达 $36.97 \mathrm{~km}^{2} / \mathrm{a}^{[12]}$. 通过钻探及野外调研发现

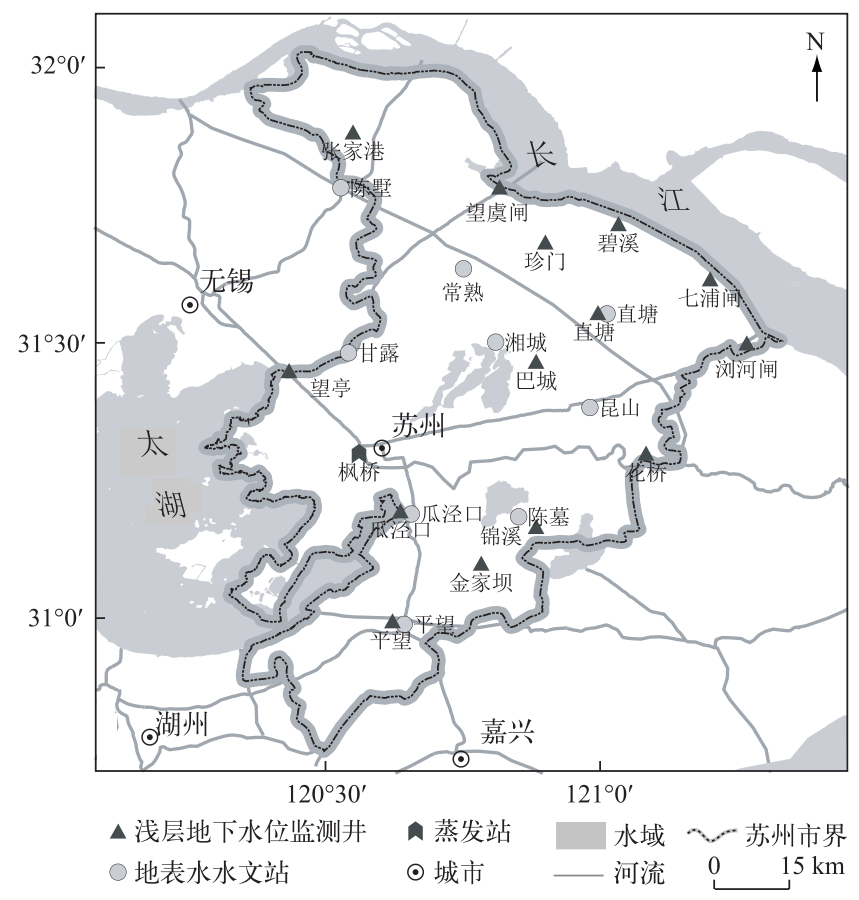

图 1 研究区位置

Fig.1 Distribution of the study area 
表面覆盖着大量的第四纪松散沉积物, 岩性以黏土、沙土及砂砾层为主. 除少数基岩裸露区以外,均有分布; 城市区则主要由杂填土、素填土组成, 富水性差, 透水性不均. 浅层地下水主要补给源为降水、地表水人渗; 消退以蒸发和侧向径流为主 ${ }^{[13]}$.

\section{2 数据情况}

本文数据源包括 2005-2015 年 14 个浅层地下水监测井浅层地下水水位和 2005-2014 年典型站点河 道水位和蒸发量的日实测资料.

\section{3 研究方法}

利用互相关法获取浅层地下水对降水过程的响应机制, 该方法在描述时间序列平稳性和滞时等方面可 靠性较高,可写成 ${ }^{[14-16]}$ :

$$
\begin{gathered}
C_{x y}(k)=\frac{1}{n} \sum_{i=1}^{n-k}\left(x_{t}-\bar{x}\right)\left(y_{t+k}-\bar{y}\right) \\
Y_{x y}(k)=\frac{C_{x y}(k)}{\delta_{x} \cdot \delta_{y}}
\end{gathered}
$$

式中, $C_{x y}$ 为互相关函数, $k$ 表示滞时, $n$ 为时间序列长度, $x_{t}$ 和 $y_{t}$ 分别表示 2 个时间序列数据, $\bar{x}$ 和 $\bar{y}$ 分别表示 $x_{t}$ 和 $y_{t}$ 序列的平均值, $Y_{x y}$ 表示互相关系数, $\delta$ 表示时间序列的标准离差. 互相关系数大于标准误差 $2 / N^{0.5}$ 时, $P<0.05, N$ 为数据序列长度.

\section{2 结果与分析}

\section{1 浅层地下水空间分布}

$2005-2015$ 年研究区浅层地下水年均水位为 $3.94 \mathrm{~m}$,水位较高的区域主要出现在西部和北部地区, 浅 层地下水主要呈由北往南、自西向东流向 (图 2a). 年均埋深为 $1.03 \mathrm{~m}$,埋深较大的区域集中在望虞闸等西北 部, 埋深较浅的站点主要出现在锦溪等东南部地区 (图 2b). 说明在降水等气象条件及地质条件相对均一的 平原水网区,地形条件是造成浅层地下水平均水位和埋深空间差异的主要因素之一.

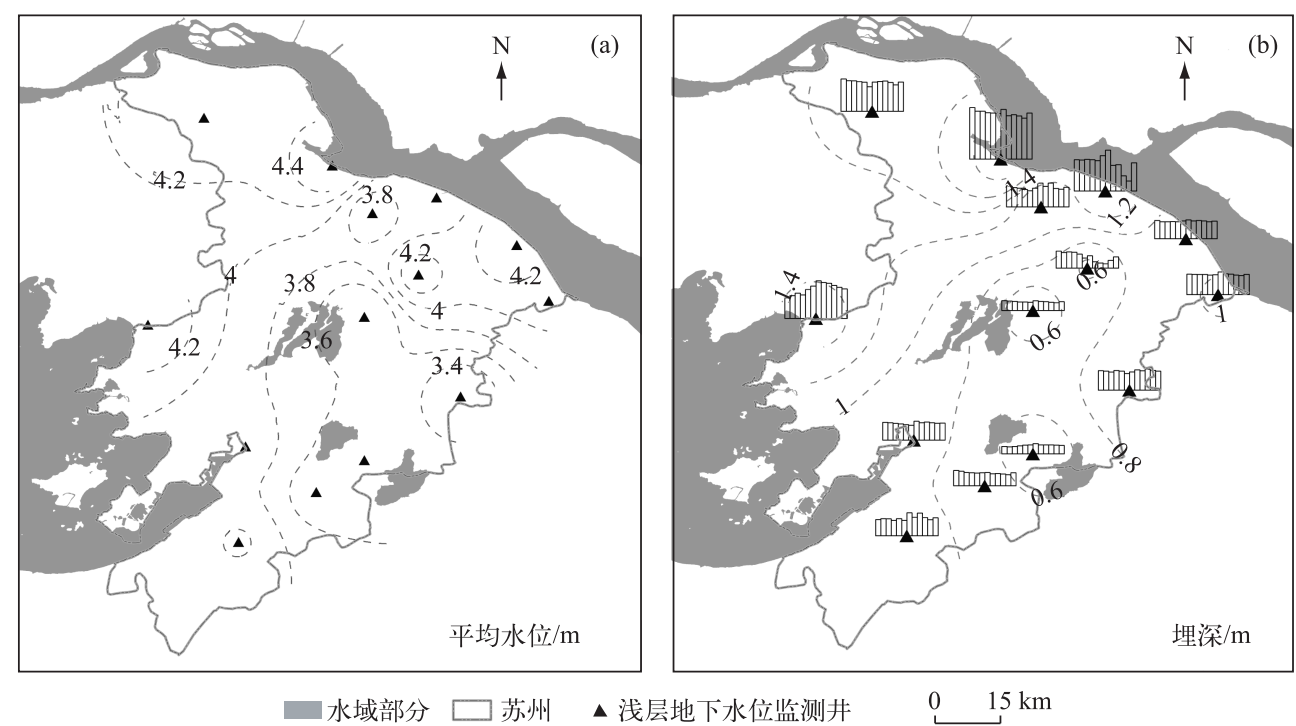

图 2 浅层地下水平均水位 (a) 与埋深 (b) 空间格局 ( $\mathrm{b}$ 图中的柱状图表示近 $11 \mathrm{a}$ 各站点浅层地下水埋深过程及多年平均值)

Fig.2 Spatial patterns of annual average shallow groundwater level(a) and burial depth(b) 


\section{2 浅层地下水埋深动态特征}

近 $11 \mathrm{a}$ 浅层地下水埋深累计减小 $0.15 \mathrm{~m}$, 波动性较大(图 3). 2005-2010 年变化过程较为平稳, 略有下 降; 2011 年埋深迅速升至最大值 (1.81 m), 其后稳步减小. 根据降水年内分布划分出丰水期 (5-10 月) 和枯 水期 (11一次年 4 月). 丰水期浅层地下水埋深呈下降趋势, 枯水期略有上升. 2005-2010 年期间, 丰、枯水期 埋深均较为稳定, 2010 年迅速增加, 其后呈下降趋势. 年际和丰枯水期浅层地下水埋深与对应时段降水量相 关系数分别为 $-0.50 、-0.66$ 和 -0.75 ( $P$ 分别小于 $0.1 、 0.01$ 和 0.01 ). 即, 浅层地下水受降水量的强烈影响, 尤 其是枯水期.

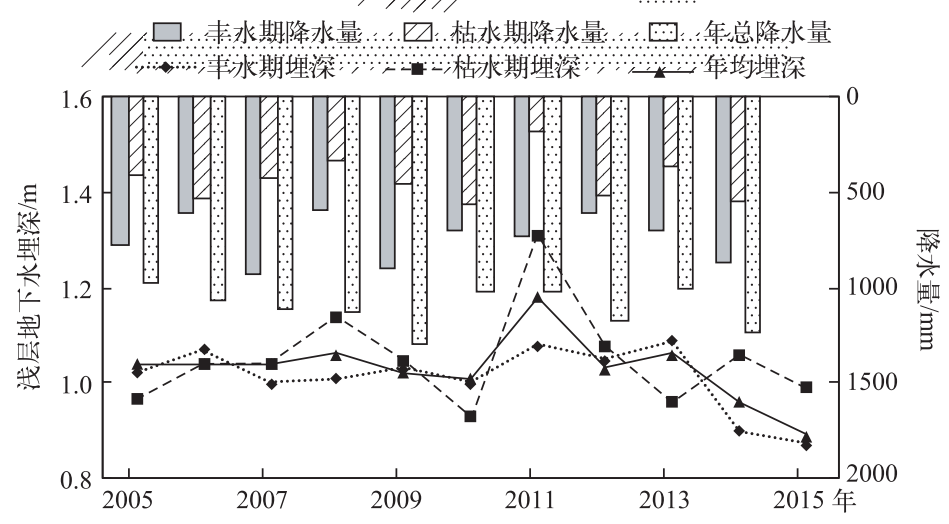

图 3 浅层地下水埋深时间序列

Fig.3 Time series of SGBD

各站点浅层地下水变化过程以下降趋势为主, 尤其是东部和北部 (图 2b). 根据变化过程可划分为 4 种 类型. 其中, 上升一下降型主要分布于西部、北部和东南部地区;下降一上升一下降型, 分布于中北部地区; 持 续下降和下降一上升较少, 空间分布较为分散. 各月份中, 仅 $1 、 2$ 和 9 月出现微弱上升. 浅层地下水埋深年内 分布呈 “W” 型 (图 4a), 月均浅层地下水埋深与降水量的相关系数为 $-0.85(P<0.01)$. 空间上, 大部分站点与 区域特征一致. 埋深最小值均出现在 7 月,最大值多出现在 1 月 (图 4b).
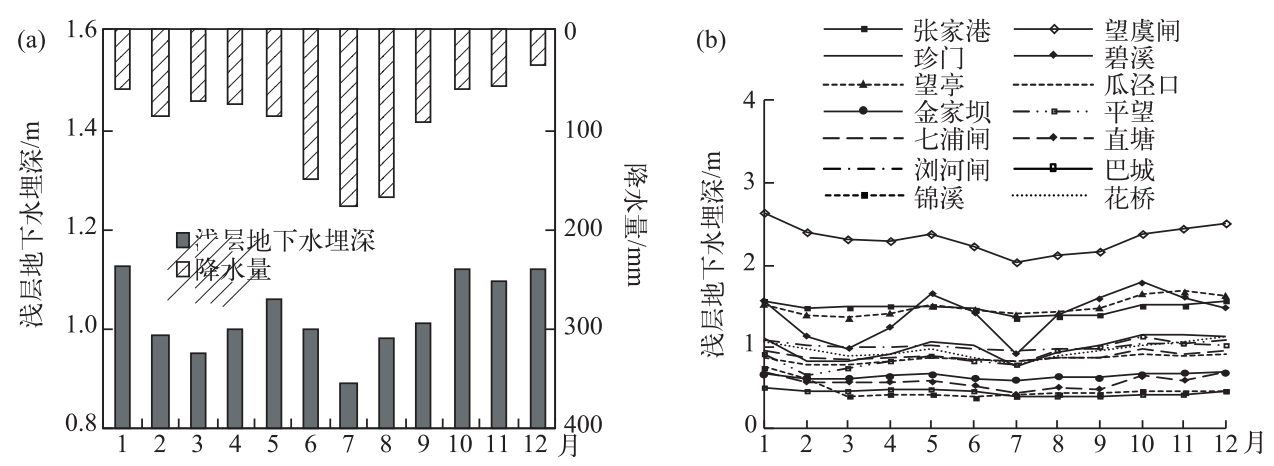

图 4 区域及各监测井浅层地下水埋深年内分布

Fig.4 Distribution of SGBD in region and station scale

\section{3 浅层地下水埋深动态特征的影响因素}

2.3.1 降水因素 2005-2014 年降水量介于 911 1349 mm 之间,主要集中在丰水期,约占全年的 53.18\% $80.46 \%$ (表 1). 从日尺度不同等级降水的总量和发生次数看, $50 \mathrm{~mm}$ 以上暴雨累计发生 18 次,均出现在丰 水期; $10 \mathrm{~mm}$ 以上降水共计 355 次, 60\% 出现在丰水期,对年降水量的贡献率介于 $56.54 \% \sim 83.14 \%$ 之间; 除 个别年份外,枯水期无雨日多在 $100 \mathrm{~d}$ 以上,显著大于丰水期. 
表 $12005-2014$ 年丰、枯水期不同降水等级降水量及次数 *

Tab.1 The amount and frequency of different precipitation ranks in wet and dry seasons from 2005 to 2014

\begin{tabular}{ccccccccccc}
\hline 降水等级 & 2005 年 & 2006 年 & 2007 年 & 2008 年 & 2009 年 & 2010 年 & 2011 年 & 2012 年 & 2013 年 & 2014 年 \\
\hline 年降水总量 & 1198 & 1131 & 1340 & 933 & 1349 & 1268 & 911 & 1130 & 1058 & 1405 \\
丰水期 降水总量 & 784 & 601 & 923 & 598 & 894 & 705 & 733 & 616 & 693 & 864 \\
$50 \mathrm{~mm}$ 以上 & $188(2)$ & $54(1)$ & $195(3)$ & $54(1)$ & $126(2)$ & - & $185(3)$ & $115(1)$ & $266(3)$ & $116(2)$ \\
$40 \mathrm{~mm}$ 以上 & $188(2)$ & $145(3)$ & $236(4)$ & $276(6)$ & $216(4)$ & - & $185(3)$ & $155(2)$ & $313(4)$ & $116(2)$ \\
$30 \mathrm{~mm}$ 以上 & $266(4)$ & $245(4)$ & $403(8)$ & $316(7)$ & $344(8)$ & $70(2)$ & $249(5)$ & $221(4)$ & $413(8)$ & $254(12)$ \\
$20 \mathrm{~mm}$ 以上 & $371(8)$ & $256(7)$ & $515(14)$ & $382(10)$ & $476(13)$ & $208(8)$ & $366(11)$ & $321(8)$ & $434(8)$ & $397(12)$ \\
$10 \mathrm{~mm}$ 以上 & $518(18)$ & $366(16)$ & $593(19)$ & $622(27)$ & $666(26)$ & $375(19)$ & $585(24)$ & $419(15)$ & $588(20)$ & $641(29)$ \\
无雨日数 & $(97)$ & $(86)$ & $(83)$ & $(79)$ & $(90)$ & $(77)$ & $(76)$ & $(88)$ & $(103)$ & $(87)$ \\
枯水期 降水总量 & 414 & 529 & 417 & 335 & 455 & 563 & 178 & 514 & 365 & 541 \\
$30 \mathrm{~mm}$ 以上 & - & $93(3)$ & $31(1)$ & - & - & - & - & - & - & $33(1)$ \\
$20 \mathrm{~mm}$ 以上 & $103(4)$ & $119(4)$ & $149(6)$ & $49(2)$ & $70(3)$ & $111(5)$ & $26(1)$ & $23(1)$ & $82(3)$ & $33(1)$ \\
$10 \mathrm{~mm}$ 以上 & $186(9)$ & $273(15)$ & $266(15)$ & $148(9)$ & $250(15)$ & $384(24)$ & $52(3)$ & $228(16)$ & $292(19)$ & $285(17)$ \\
无雨日数 & $(103)$ & $(108)$ & $(104)$ & $(104)$ & $(105)$ & $(91)$ & $(130)$ & $(93)$ & $(100)$ & $(111)$ \\
\hline
\end{tabular}

* 表中数据表示降水量 $(\mathrm{mm})$, 括号中的数字表示发生次数;一表示未发生.

降水是浅层地下水重要的补给来源, 其季节和年际分配不均, 导致旱涝交替现象时有发生, 并对浅层地 下水埋深变化过程有着重要的驱动作用. 枯水期偶有强降水发生, 并造成浅层地下水埋深的快速减小; 枯水 期极旱年份,浅层地下水失去重要补给源,埋深较大.

月尺度浅层地下水埋深与降水量关系显著. 当降水量较前一月增加时, $69.31 \%$ 的月份浅层地下水埋深 有所减小; 当降水量较前一月减少时, $84.21 \%$ 的月份浅层地下水埋深有所加大. 枯水期浅层地下水埋深变化 特征与不同量级降水总量和次数呈显著相关. 其中, 与 $20 \mathrm{~mm}$ 以上级别降水总量和次数的相关系数分别为 -0.78 和 -0.77 , 与 $10 \mathrm{~mm}$ 以上级别降水总量和次数相关系数分别达 -0.96 和 -0.94 , 与无雨日数的相关系数 为 $-0.87(P<0.01)$; 丰水期水循环过程更为复杂, 浅层地下水埋深与降水量级关系不显著.

浅层地下水埋深相对于区域大气降水过程具有一定的滞后性, 且存在区域差异. 因此, 采用互相关分析 方法揭示近 $10 \mathrm{a}$ 太湖平原水网区各监测井日尺度浅层地下水埋深对降水的平均响应程度和时间, 鉴别浅层 地下水埋深变化是否受到其他因素的影响 (图 5). 首先, 瓜泾口等东部和南部浅层地下水埋深变化对降水 十分敏感, 上升和回落过程较快, 互相关系数峰值均在 0.3 以上 $(P<0.05)$, 滞后时间均为 $1 \mathrm{~d}$ 左右; 其次, 北 部和西北部的珍门、碧溪和望亭等站点退水过程缓慢,滞后时间多在 $2 \mathrm{~d}$ 及以上.

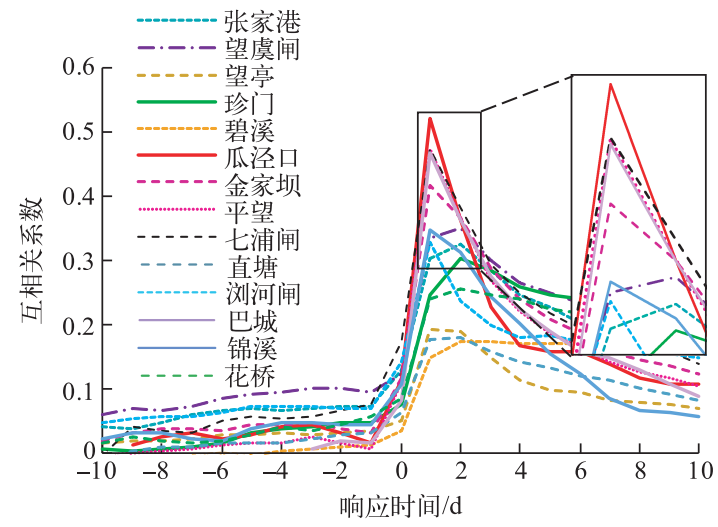

图 5 降水和浅层地下水埋深的互相关

Fig.5 Cross-correlation between precipitation and SGBD 
2.3.2 地表水和蒸发因素 从月尺度看, 年、汛期和非汛期浅层地下水埋深与河道水位的相关系数分别为 $-0.49 、-0.56$ 和 $-0.44(P<0.01)$. 采用偏相关法剔除降水影响, 探究河道水位与浅层地下水埋深的关系, 结 果发现, 年、汛期和非汛期偏相关系数分别为 $-0.21 、-0.32$ 和 -0.36 , 仅非汛期时 $P<0.05$, 说明非汛期河道水 对浅层地下水影响程度较大. 采用相同方法还发现, 蒸发因素对浅层地下水的影响较小.

2.3.3 其他因素 除以上因素外,浅层地下水埋深还受到人类活动的强烈干扰. 太湖流域为中国经济最为发 达的区域,水体污染严重. 因此, 常在枯水期开展如 “引江济太”等引水工程改善水质. 据统计, 2006-2015 年长江沿岸闸坝年均引水量达 $2.58 \times 10^{9} \mathrm{~m}^{3}$ (表 2). 其中, 望虞闸引水量最大, 累计达 $1.92 \times 10^{10} \mathrm{~m}^{3}$. 引水工程 使得河道水位抬升增加,河水与浅层地下水补给关系发生变化,尤其是枯水期.

表 $22006-2015$ 年长江沿岸引水情况 $\left(\times 10^{7} \mathrm{~m}^{3}\right)$

Tab.2 The amount of diverted water in Yangtze River coast during 2006-2015

\begin{tabular}{lcccccccccc}
\hline 引水闸 & 2006 年 & 2007 年 & 2008 年 & 2009 年 & 2010 年 & 2011 年 & 2012 年 & 2013 年 & 2014 年 & 2015 年 \\
\hline 张家港闸 & 12.76 & 10.13 & 6.23 & 14.52 & 9.11 & 3.09 & 0.22 & 1.33 & 2.55 & 4.48 \\
十一圩港闸 & 4.49 & 3.18 & 0.85 & 1.58 & 1.42 & 1.69 & 1.10 & 1.19 & 1.07 & 1.28 \\
望虞闸 & 152.70 & 238.60 & 215.20 & 124.20 & 222.80 & 299.90 & 157.60 & 220.80 & 194.20 & 96.84 \\
浒浦闸 & 14.32 & 12.91 & 13.47 & 12.13 & 4.99 & 9.31 & 0.56 & 3.84 & 1.06 & 1.53 \\
白帅闸 & 16.63 & 20.99 & 21.87 & 16.38 & 6.36 & 11.56 & 1.83 & 5.78 & 1.13 & 2.31 \\
七浦闸 & 10.34 & 10.22 & 7.61 & 5.19 & 3.13 & 5.07 & 1.81 & 4.62 & 2.99 & 1.55 \\
杨林闸 & 12.10 & 13.89 & 11.86 & 7.77 & 4.11 & 6.46 & 1.54 & - & - & - \\
汶河闸 & 50.36 & 57.92 & 50.60 & 34.67 & 13.24 & 28.82 & 7.31 & 22.46 & 15.35 & 8.62 \\
合计 & 273.70 & 367.84 & 327.69 & 216.44 & 265.16 & 365.89 & 171.98 & 260.02 & 218.33 & 116.61 \\
\hline
\end{tabular}

同时,强烈的人类活动造成该区域下垫面特征剧烈变化. 首先, 快速城镇化进程导致区域不透水面积增 加, 水田面积大幅减少. 通过对太湖腹部武澄锡虞和阳澄淀泖水利片区土地利用类型解译发现, 水田面积所 占比例由 1991 年的 74.28\%下降到 2009 年的 $41.54 \%$, 城镇用地则由 $10 \%$ 左右上升到 $40 \%$ 以上. 不透水面积 的大幅扩张, 改变了区域水文过程, 影响了降水对浅层地下水的短历时补给过程. 其次, 该区域地势低平排 水不畅, 又是太湖流域主要的排洪通道. 为应对洪涝问题, 相关部门对区域河湖水系进行了重新规划与调 整, 导致区域水系数量、结构和连通程度均发生了剧烈变化. 主要表现为水系数量减少, 尤其是低等级河道. 此外, 修建了众多的闸坝泵站工程. 据统计, $1970 \mathrm{~s}$ 以来, 太湖腹部地区共修建了大小闸坝枢纽约 2488 个, 其 中 2000s 修建个数多达 1484 个. 因此, 研究区河网结构和水力连通程度具有较大变化. 河道水位在很大程度 上受人为控制,与自然河流差别较大,改变了河水与浅层地下水的相互补给关系.

\section{4 浅层地下水特征类型分析}

由前文可知,造成研究区浅层地下水动态特征差异的因素主要包括地形地貌、土地利用类型、河湖密度 以及浅层地下水埋深状况等. 因此, 选取以上因素, 通过空间等权重叠加, 分析浅层地下水动态特征类型 (图 6).

根据下垫面特征,苏州市浅层地下水特征包括耕地区、水网密布区、高度城镇化区和低山林区 4 种类型 (图 6). 首先, 长江沿岸地区耕地面积比重大, 浅层地下水埋深较大; 其次, 苏州市的阳澄湖、澄湖、淀山湖周 边地区及西南部太湖沿岸区, 湖荡众多, 水面率极高, 浅层地下水动态特征受到地表水的影响相对较大; 第 三, 高度城镇化区主要位于苏州一昆山一线以及张家港、常熟城区, 不透水面比例较高, 并造成下覆土层发生 变化, 导致降水对浅层地下水的补给作用发生变化; 最后, 苏州市西部太湖沿岸以及常熟虞山地区为仅有的 地势较高、坡度较大的区域,下垫面以林地为主,浅层地下水分布相对较少.

通过对苏州市浅层地下水埋深变异系数与平均埋深关系分析发现 (图 7) : 首先,锦溪、巴城、金家坝等水 网密布区站点浅层地下水与地表水关系密切, 其埋深变化过程相对平缓, 且对降水的响应更加显著 (图 5); 反之, 碧溪、汶河闸等北部高埋深耕地区变异系数更大; 张家港和望虞闸 2 站浅层地下水埋深最大, 由于受 到高度城镇化的影响, 浅层地下水对蒸发的补给作用和对降水的响应关系相对较弱, 浅层地下水埋深较大, 但变异系数较小. 


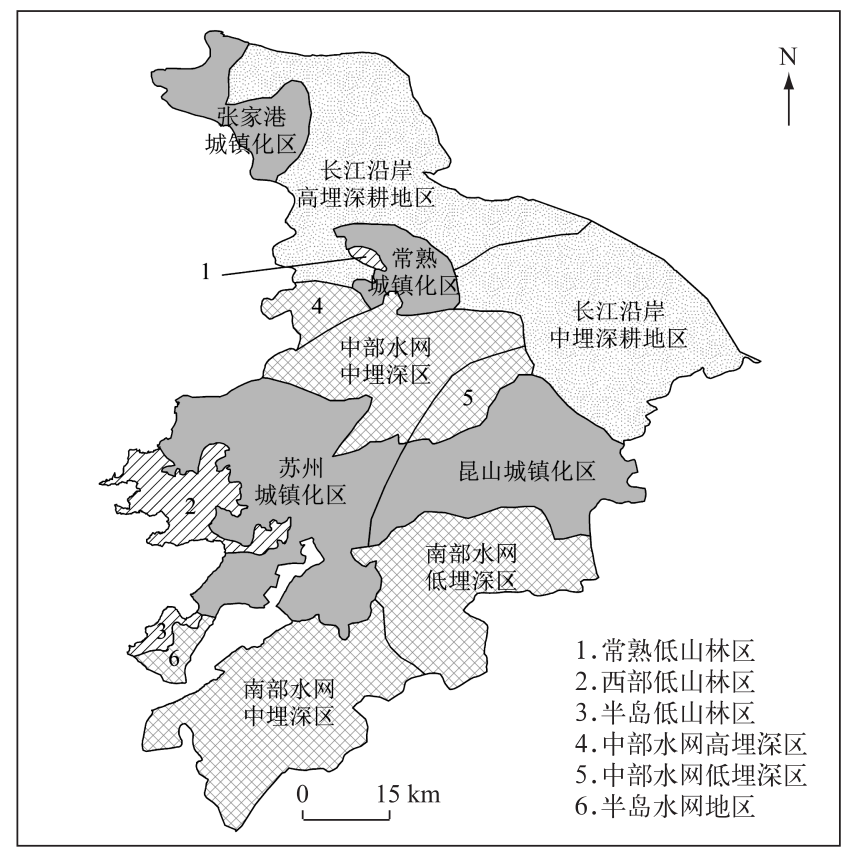

$\square$ 耕地区 $\square$ 水网密布区 $\square$ 高度城镇化区 $\square / 7$ 低山林区

图 6 苏州市浅层地下水特征分类图

Fig.6 Categories of SGBD variation characteristics in Suzhou City

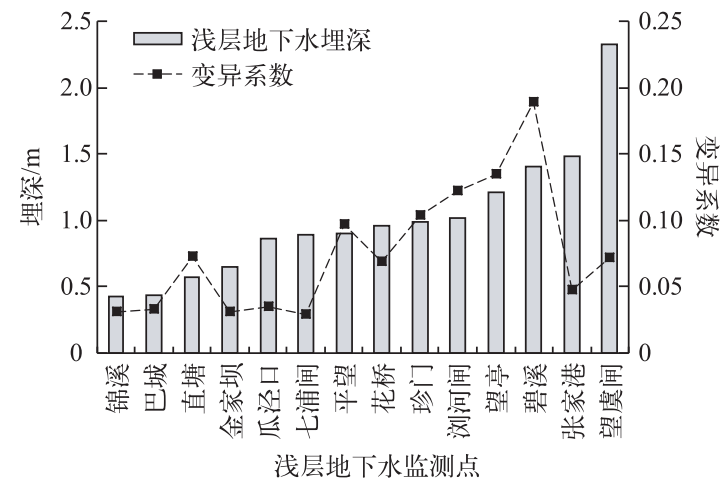

图 7 苏州市浅层地下水埋深与变异系数

Fig.7 Relationship between SGBD and its variation coefficient in Suzhou City

\section{3 结论}

基于太湖腹部典型地区苏州市的 14 个浅层地下水观测井 2005-2015 年日尺度埋深实测数据, 从空间 分布及不同时间尺度的动态特征进行分析; 并结合研究区 2005-2014 年的降水、河流水位及蒸发量日尺度 实测资料,利用相关及偏相关分析等方法,探讨了浅层地下水埋深动态的影响因素. 主要结论如下:

1) 空间上,受海拔高程影响,2005-2015 年浅层地下水埋深与水位的空间对应关系较好,呈现由北往 南、自西向东的流向. 埋深较大的区域主要集中在西部和北部地区,埋深较浅的区域为东南部区域; 时间上, 年际和丰水期浅层地下水埋深略有下降, 枯水期反之, 区域变化过程并不一致. 其中, $1 、 2$ 和 9 月浅层地下水 
埋深有微弱上升;年内分布呈“W”型分布, 区域差异较大.

2) 枯水期浅层地下水过程与不同量级降水总量和次数均显著相关,丰水期不显著. 浅层地下水埋深对 降水具有滞后性, 多在 $1 \sim 2 \mathrm{~d}$; 浅层地下水埋深动态过程主要受降水量影响, 非汛期还受到地表水的影响. 此 外,区域引排水和下垫面变化也是重要影响因素.

3 ) 通过对地形地貌条件、土地利用类型、河湖密度以及浅层地下水埋深状况等因素的等权重叠加发现， 苏州市浅层地下水动态特征主要有耕地区、水网密布区、高度城镇化区和低山林区 4 种类型特征, 且埋深差 异显著. 其中, 水网密布区浅层地下水埋深变异系数较小, 对降水的响应更显著; 耕地区由于浅层地下水埋 深较大, 与水网密布区反之; 高度城镇化区浅层地下水埋深较大,但变化过程相对平缓.

\section{4 参考文献}

[ 1 ] Sanderson JS, Cooper DJ. Ground water discharge by evapotranspiration in wetlands of an arid intermountain basin. Journal of Hydrology, 2008, 351 : 344-359.

[ 2 ] Cai ZS, Ofterdingter U. Analysis of ground water-level response to rainfall and estimation of annual recharge in fractured hard rock aquifers, NW Ireland. Journal of Hydrology, 2016, 535: 71-84.

[ 3 ] Barron OV, Barr AD, Donn MJ. Effect of urbanization on the water balance of a catchment with shallow groundwater. Journal of Hydrology, 2013, 485: 162-176.

[ 4 ] Dakhlalla AO, Parajuli PB, Ouyang Y. Evaluating the impacts of crop rotations on groundwater storage and recharge in an agricultural watershed. Agricultural Water Management, 2016, 163: 71-84.

[ 5 ] Alexandra G, Kyriakos S. Evaluation of the effects of climate and man intervention on ground waters and their dependent ecosystems using time series analysis. Journal of Hydrology, 2011, 403: 130-140.

[ 6 ] Qi XF, Yang LZ, Han Y et al. Cross wavelet analysis of groundwater level regimes and precipitation-groundwater level regime in Ji'nan Spring Region. Advances in Earth Science, 2012, 27(9): 969-978. [祁晓凡, 杨丽芝, 韩晔等. 济南泉域 地下水位动态及其对降水响应的交叉小波分析. 地球科学进展, 2012, 27(9): 969-978.]

[ 7 ] Xia J, Liu N, Gao HW et al. The analysis on impact of shallow groundwater recession to regional climate of Shangqiu City. Acta Ecologica Sinica, 2010, 30(16) : 4408-4415. [夏晶, 刘宁, 高贺文等. 商丘市浅层地下水位下降对区域气候的 影响. 生态学报, 2010, 30(16): 4408-4415.]

[ 8 ] Li SN, Wang GX, Deng W et al. Variation of groundwater depth in Yellow River Delta in recent two decades. Process in Geography, 2008, 27 (5): 49-56. [李胜男, 王根绪, 邓伟等. 黄河三角洲典型区域地下水动态分析. 地理科学进 展, 2008, 27(5): 49-56.]

[ 9 ] Wang SQ, Song XF, Wang QX et al. Dynamic features of shallow groundwater in North China Plain. Acta Geographica Sin$i c a, 2008,63(5):$ 462-472. [王仕琴, 宋献方, 王勤学等. 华北平原浅层地下水水位动态变化. 地理学报, 2008, 63( 5$): 462-472$.]

[10] Yang J, Chen HS, Nie YP et al. Variation of precipitation characteristics and shallow groundwater depth in the typical karst peak-cluster depression areas. Journal of Soil and Water Conservation, 2012, 26 (5) : 239-243. [杨静, 陈洪松, 聂 云鹏等. 典型喀斯特峰丛洼地降雨特性及浅层地下水埋深变化特征. 水土保持学报, 2012, 26(5): 239-243.]

[11] Deng QJ, Tang ZH, Wu Q et al. Characteristics of groundwater and its influencing factors in Jingzhou City. Resources and Environment in the Yangtze River Basin, 2014, 23(9): 1215-1221. [邓青军, 唐仲华, 吴琦等. 荆州市地下水动态特 征及影响分析. 长江流域资源与环境, 2014, 23(9): 1215-1221.]

[12] Ji D, Zhang H, Shen WS et al. The response relationship between underlying surface changing and climate change in the Taihu Basin. Journal of Natural Resources, 2013, 28(1): 51-62. [纪迪, 张慧, 沈渭寿等. 太湖流域下垫面改变与气 候变化的响应关系. 自然资源学报, 2013, 28(1) : 51-62.]

[13] Cheng X, Chen HS. Questions and measures for the groundwater and geologic environment in Taihu Basin. Symposium of the 1st Youth Science and Technology Forum by China Institute of Water Resources, 2003. [成新, 陈荷生. 太湖流域地 下水与地质环境问题及对策. 中国水利学会首届青年科技论坛论文集, 2003.]

[14] Fest D, Liang DW. Measuring the short term frequency stability of oscillator by use cross-correlation method. Telecommunication Engineering, 1984，(1) : 63-66. [ Fest D, 梁德文. 采用互相关法测量振荡器的短期频率稳定性. 电讯技术, 1984 , (1): 63-66.]

[15] Mangin A. The use of auto-correlation and spectral analysis to obtain a better understanding of hydrological systems. Journal of Hydrology, 1984, 67: 25-43.

[16] Sang YF, Wang D, Wu JC et al. Wavelet cross-correlation method for hydrologic time series analysis. Journal of Hydraulic Engineering, 2010, 51(11): 1272-1279. [桑燕芳, 王栋, 吴吉春等. 水文时间序列小波互相关分析方法. 水利学 报, 2010, 51(11): 1272-1279.] 